\title{
Bankruptcy Exemptions and the Market for Mortgage Loans
}

\author{
Richard Hynes \\ University of Pennsylvania
}

\author{
Jeremy Berkowitz \\ Federal Reserve Board
}

November 11, 1996

This Draft: February 26, 1998

\author{
Address correspondence to: \\ Jeremy Berkowitz \\ Federal Reserve Board \\ 20th and C Streets, N.W. \\ Washington, D.C. \\ jberkowitz@frb.gov
}

\begin{abstract}
The recent explosion in personal bankruptcy filings has motivated research into whether credit markets are being adversely affected by generous legal provisions.

Empirically, this question is examined by comparing credit conditions and bankruptcy exemptions across states. We note that the literature has focused on aggregate household credit, making no distinction between secured and unsecured credit. We argue that such aggregation obscures important differences in forms of credit. Most significantly, property exemptions do not prevent the home mortgage creditor from foreclosing on the home if not fully repaid. We argue that some property exemptions may in fact have some beneficial effects for home mortgage lenders. Using both household-level data and state-level data, we show that in the 1990's high exemption levels have tended to reduce mortgage rates and reduce the probability of being denied a mortgage.
\end{abstract}

Acknowledgements: We gratefully acknowledge helpful input from Raphael Bostic, Steven Coate, Arthur Kennickel, Steven Morris, Eric Posner, Nicholas Souleles, Martha StarrMcCluer, Petra Todd and Michelle White. All remaining errors and inaccuracies are ours. The opinions expressed herein do not necessarily represent those of the Federal Reserve Board or its staff. 


\section{Introduction}

Personal bankruptcy is no longer an unusual phenomenon. Personal bankruptcy filings have risen over 500\% in the last two decades and there were over 1 million filings in 1996 alone. ${ }^{1}$ Moreover, these filing statistics may in fact understate the importance of personal bankruptcy as many more debtors may implicitly use the threat of filing to evade collection efforts by their creditors; it is default and not necessarily bankruptcy which creates losses for creditors (see White and Petropolous (1996)).

The possibility that these changes in bankruptcy patterns may affect the larger market for credit is of obvious importance to economists and the general public. Yet, to date there has been surprisingly little research in this area. In one recent exception, Gropp Scholz and White (1997) used the 1983 Survey of Consumer Finance to test the question of whether differences in state bank exemption levels affect aggregate household credit.

Aggregate household credit, though, contains both secured and unsecured credit which have very different dispositions in bankruptcy. As a result, the effects of bankruptcy on aggregate credit may obscure important differences in the underlying components of household credit. In this paper, we argue that much of the conventional wisdom regarding bankruptcy does not apply to secured credit. In particular, we focus on the primary market for household credit -- the market for mortgage loans.

Mortgage loans are (nearly always) fully secured by a combination of collateral, downpayment and mortgage insurance. Over $97 \%$ of the secured claims of Savings and Loans and private mortgage companies on bankrupt debtors are fully secured (Sullivan, Warren and Westbrook (1989). ${ }^{2} \quad$ Unlike credit card companies or other unsecured lenders, the mortgage lender always has legal remedies, namely the right to repossess. The mortgage lender is senior to bankruptcy exemptions with respect to its collateral.

In addition to approximating fully secured credit, mortgage debt plays a central role in

\footnotetext{
${ }^{1}$ Taken from the Administrative Office of the U.S. Courts, Annual Report of the Director 1996.

${ }^{2}$ As a consequence, while losses on personal loans amounted to about $2 \%$ of total, losses on second mortgages were only .19\% in 1992 (Installment Credit Report (1992)).
} 
the portfolio of many households. Home mortgage loans represented $68 \%$ of the liabilities of households in 1995. ${ }^{3}$ Mortgage loans are also prominent in bankruptcy; in a sample studied by Sullivan, Warren and Westbrook (1989), 53\% of bankrupt debtors were homeowners and, in this group, mortgage loans constitute more than half of their debts.

We emphasize that the institutional and legal realities of personal bankruptcy are not consistent with the so-called "simple hypothesis" which drives much of the empirical literature. The hypothesis maintains that generous bankruptcy provisions increase the demand for credit and encourage bankruptcy. We detail several legal obstacles which work to prevent debtors from intentionally building-up unsecured debts prior to bankruptcy. As a result, we stress that to the extent that bankruptcy laws influence credit markets, they operate primarily through the supply of credit.

The role of the home as collateral and the existence of several legal protections provided to the home mortgage lender in bankruptcy make it unlikely that homestead exemptions could adversely affect the mortgage credit market. In addition, it is possible that the home mortgage lender may gain from these exemptions and bankruptcy. Put simply, many debtors file for bankruptcy precisely so that they can pay their mortgage and keep their home by discharging other debts. ${ }^{4}$

Our empirical investigation makes use of both time series and cross-sectional variation. The Home Mortgage Discrimination Act (HMDA) dataset and the Federal Housing Finance Board's Rates and Terms on Conventional Home Mortgages provide cross-sectional data over several years. To our knowledge, this paper is the first to use these large highquality data sets to study of the effects of bankruptcy.

The remainder of the paper proceeds as follows. Section 2 provides a brief outline of the relevant empirical evidence. Section 3 discusses some aspects of the legal structure of the credit market and why it is so difficult to construct an empirical test. Section 4 presents a

${ }^{3}$ See Kennickell, Starr-McCluer and Sunden (1997).

${ }^{4}$ Sullivan, Warren and Westbrook (1989) report that $10 \%$ of homeowners in bankruptcy do not even report their mortgages to the court. They estimate that $40 \%$ of debtors in bankruptcy reaffirm some form of secured debt. 
framework for examining the effects of property exemptions on the mortgage market. Section 5 reports empirical estimates of the importance of exemption levels on the market for housing credit. Section 6 concludes.

\section{Existing Literature}

Although bankruptcy is governed by federal law, the states are permitted to set their own exemption policies and have been kind to empirical economists by enacting what seems to be wildly different exemption policies. ${ }^{5}$ Several authors have tested the hypotheses that, by making bankruptcy more attractive, large exemptions should lead to an increase in the filing rate. ${ }^{6}$ White (1987) found a positive relationship between the size of a state's exemption and the number of filings that was statistically significant, but weak. Many other scholars found either no statistically significant relationship or even a negative relationship between the generosity of a state's exemption and the number of filings (e.g., Peterson and Aoki (1984), Shiers and Williamson (1987) and Buckley and Brinig (1996)). Hynes (1998) finds that while this ambiguity is not resolved by examining panel-data or the quasi-experiment created by the change in the federal exemptions in 1994.

A recent article by Gropp, Scholz and White (1997) (GSW) uses the 1983 Survey of Consumer Finance to test the broader question of whether differences in states' bankruptcy exemption levels affect aggregate household credit (both secured and unsecured). They found that exemption changes were having a significant effect (see Domowitz and Eovaldi (1993) for opposing arguments). Specifically, GSW found that, when controlling for other factors, relatively large state bankruptcy exemptions are associated with 1) higher probabilities of

${ }^{5}$ For example, a bankrupt debtor in Maryland may only use a \$5,500 wildcard exemption to try to keep both his car and his house under Chapter 7. In Texas, a bankrupt debtor may exempt his home regardless of its value as long as it is on a lot of less than one acre (200 acres if outside a municipality) and could potentially exempt automobiles worth $\$ 60,000$. Exemptions cover objects as diverse as a leased organ (Delaware) to dead bodies (Rhode Island).

${ }^{6}$ These studies did not address the fact that the exemptions have legal significance both in and out of bankruptcy. We argue below that, despite this oversight, the hypothesis is still likely to be confirmed. 
being denied credit; 2) high total borrowing for households in the top half of the asset distribution; 3) low borrowing for households in the bottom quartile of the asset distribution; and 4) higher interest rates on automobile loans for low-asset households. Clearly, the GSW paper raises some very important questions.

The results for low asset debtors are consistent with previous theoretical work on exemptions (e.g., Shiers and Williamson (1987)) but present at least one empirical puzzle. GSW assert that the exemptions cause an increase in the demand for credit and a reduction in the supply of credit and that the supply shift may dominate for the low asset debtors while the demand shift dominated for the high asset debtors.

However, that GSW find effects at all for low asset debtors is surprising. By their definition, low asset debtors have less than $\$ 7,885$ in assets. Given their estimate of the aggregate exemption level, which combines the homestead and non-homestead exemptions, these debtors should be able to exempt all of their assets in all but four states. Thus, nearly all of the variation in exemption levels is irrelevant to low asset debtors and their creditors.

More importantly, GSW study the effect of different exemption levels on the probability of being denied credit regardless of whether the credit is secured or unsecured. The Survey of Consumer Finance asks whether the debtor has been denied credit, not whether this credit was secured or unsecured (see Avery, Ellihausen and Kennickell (1988)). ${ }^{7}$ Similarly, the quantity of credit and interest rate variables which they examine also aggregate these two kinds of credit. ${ }^{8}$ This assumption is justified by the debtor's ability to "arbitrage assets and debts across categories." The authors suggest that debtors could borrow on their credit cards or obtain a new consumer loan in order to reduce their mortgage. As detailed below, this kind of strategy is risky. Moreover, the possibility of using this strategy

${ }^{7}$ This may explain the differential results for low asset and high asset debtors found by GSW. Low asset debtors may be more likely to require unsecured credit than high asset debtors. Since bankruptcy exemptions are less likely to affect secured credit (whose collateral can always be repossessed) than unsecured credit, high asset debtors appear unhindered by relatively high exemption levels.

${ }^{8} \mathrm{GSW}$ use interest rates from auto loans. Because these loans are often undersecured in bankruptcy, their interest rate measure reflects both secured and unsecured credit components. 
prejudices the creditor in favor of secured rather than unsecured loans. A successful execution of the strategy results in the mortgage holder getting paid, while the unsecured creditor bears the loss.

Secured debt and, in particular, mortgage debt is granted very different legal treatment than unsecured debt in bankruptcy. Aggregating these two forms of credit may obscure differential responses to the prospect of bankruptcy. This paper focuses on home mortgages; the effect on unsecured loans is left to future work.

In the next section, we provide detailed background on the treatment of mortgage and unsecured debt in bankruptcy.

\section{The Confusing Law of Property Exemptions}

In most states the debtor can choose either the state property exemptions or the federal section 522(d) exemptions. ${ }^{9}$ This paper considers both the $\$ 522(\mathrm{~d})$ bankruptcy exemptions and state property exemptions. If a debtor files under Chapter 7 , he will be entitled to exempt the equity in his assets up to the value specified in the exemptions. The exemptions will also have significance in Chapter 13 through the "best interests of the creditors" test which states that the creditors are entitled to receive at least as much in Chapter 13 as they would have received in Chapter 7 (Section 1325(a)(4) of the Federal Bankruptcy Code).

\section{3a. What are the characteristics of property exemptions?}

Empirical investigations would be much easier if the variation between state property exemption was based solely on generosity; for example if all states enacted exemptions which allowed the debtor to choose the form of exempt property. Almost half of the states do provide a "wildcard" exemption which allows a debtor to choose at least some of his exemption and some states have "spillover" provisions in their homestead exemption which allows a debtor without a home to use some of the homestead exemption for other purposes. ${ }^{10}$

${ }^{9}$ Some states do not permit use of the federal exemptions.

${ }^{10} \mathrm{~A}$ "wildcard" exemption is available in 24 states and the District of Columbia. However, in 18 of these states the exemption is below $\$ 1,000$. 
However, even in these states the "wildcard" or "spillover" exemptions are but one of many exemptions available to the debtor.

The homestead exemption is typically the most generous property exemption in a state and certainly the most significant exemption for this paper. A homestead exemption allows a debtor to exempt the equity in his home.

Despite popular belief, no homestead exemption is truly "unlimited." Those that do not contain a dollar limit contain a limit on the lot size. Although some of these limits are quite large for rural areas, it is quite easy to imagine that the limitation becomes binding for wealthier debtors in towns, cities or villages. For example, in Arkansas a debtor claiming an exemption in a city, town or village can obtain an unlimited exemption only if his homestead is under $1 / 4$ of an acre. If the homestead is between $1 / 4$ and 1 acre, the homestead exemption is limited to $\$ 2,500$. No homestead may exceed 1 acre in a city, town or village. Apparently those debtors owning more than 1 acre in the town must choose the second option of up to $\$ 1,250$ if married; an amount which is not scandalously large. Of course, a home on $1 / 4$ of an acre may still be worth quite a bit and many of the homestead exemptions, including those with a specific dollar limit, are so valuable relative to the assets of the debtor as to be effectively unlimited. A home is an excellent store of wealth and the debt may be fungible by paying down the mortgage, however even this strategy has its limits.

Even when a state places a limit on the amount of equity that a debtor may exempt, that limit often depends on the characteristics of the debtor. For example, some states allow married debtors filing jointly to each claim a homestead exemption while other states do not. Some states, such as Massachusetts, offer substantially increased exemptions for senior citizens while other states such as Utah and Virginia offer exemptions which depend on the number of dependents that a debtor has. Finally, as mentioned above, the exemption may depend critically on whether a debtor lives in a rural or urban area.

When examining personal property exemptions, the first thing that one will notice, even before the generosity of some state's exemption schemes, is that most states offer schemes that are highly specific and complex. A quick glance at the tangible personal property that can be exempted in Texas will illustrate this point. In Texas the debtor may exempt "athletic and sporting equipment, including bicycles; 2 firearms; home furnishings, 
including family heirlooms; food; clothing; jewelry (not to exceed 25\% of total exemption); 1 two-, three- or four-wheeled motor vehicle per member of the family or single adult who holds a driver's license . .; 2 horses, mules or donkeys and a saddle, blanket and bridle for each; 12 head of cattle, 60 head of other types of livestock; 120 fowl; pets and tools, equipment \& books to $\$ 30,000$ total $\left(\$ 60,000\right.$ for head of family). ${ }^{11}$ With all of this incredible specificity, the personal property exemption is substantially more difficult to quantify than the homestead exemption.

\section{3b. The Pitfalls of Quantifying the Exemptions}

Because of the complications discussed above, one cannot develop a "correct" method of coding property exemptions, a situation reflected by the fact that, to our knowledge, no two papers in this area employ the same method. Indeed, GSW themselves use one measure of exemptions when studying the probability that an individual will be denied credit and a different measure when studying the effect on the quantity of credit and the interest rate. Acknowledging the potential for subjectivity, we employ multiple coding methods to insure that our results are not sensitive to the specification chosen.

The difficulties in coding the exemptions are most severe with the personal property exemptions. As described above, states are highly inconsistent in their treatment of personal property exemptions. Many states place no dollar limit on the amount of some forms of personal property that may be exempted but instead rely on words such as "necessary." Other states group categories of exemptions in unique ways and then provide a cap for the group. Still other states rely very heavily on wildcard exemptions. Therefore, if one takes the fungibility of wealth seriously and ignores the "necessary" limitations, states with no limit on the exemption of clothes, furniture or automobiles will erroneously be seen as providing "unlimited" bankruptcy exemptions. If one ignores exemptions of specific property and focuses solely on the ability to exempt cash, one will overstate the relative generosity of states that rely heavily on the wildcard exemption. One could specify dollar values for what is "necessary," but this raises serious questions about the source of the values chosen.

\footnotetext{
${ }^{11}$ From Elias, Renauer and Leonard (1995).
} 
Indeed, the exemptions may be designed to prevent the store of wealth and make resale difficult.

Another difficulty is that most debtors in financial distress are constrained in the amount that they may exempt by the total amount and type of assets that they have available; they are unable to fully utilize the exemptions as provided by law. There are two reasons for this. First, while creditors may unwittingly lend some money to debtors in financial distress, they are unlikely to grant such debtors unlimited credit. Second, there are several provisions of the bankruptcy code designed to prevent abuse of the system which, although not perfect, probably have a real effect on the ability of a debtor to "plan" for bankruptcy. The provisions we discuss below prevent a debtor from accumulating enough assets to maximize the exemptions and prevent a debtor from converting all of the assets that he does have into exempt form.

Although debtors probably borrow some money from unsecured creditors to accumulate more exempt assets, this strategy is limited both by law and by the creditors right to say no; we focus on the legal restrictions. If the court finds behavior which suggests that the debtor has borrowed with no intention of ever repaying, the courts may deny her bankruptcy petition on the grounds that it was fraudulent (Section 727) or a "substantial abuse" (Section 707(b)) of the system. Charging one's credit cards to the limit to obtain exempt assets is not necessarily a wise strategy either as debts incurred when there is no possibility to repay are non-dischargeable. Some credit card companies make use of this provision by routinely examining the bankruptcy filings of their debtors to determine the date of insolvency. They then challenge all debts incurred after this date (Elias, Renauer and Leonard (1995)). When they do challenge a debt, the banks have a fairly high success rate, between 38\% and 48\% (Installment Credit Report (1992)).

Both the provisions of the code that are designed to prevent "abuse" of the bankruptcy process and the design of the exemptions themselves work to prevent many debtors from reaching the dollar limit of each form of exempt property. That is, many exemptions explicitly give judges discretion over what the debtor is entitled to keep in order to prevent the debtor from using exempt property as a store of wealth. For example, exemptions which relate to common forms of personal property generally require that the exempt property be 
"reasonably necessary" for the debtor's livelihood or that the property be for the actual use of the debtor. ${ }^{12}$

Further, the ability of a debtor to engage in pre-bankruptcy planning, even if it is just to convert non-exempt wealth to exempt form, is limited by the existence of very fact-specific rulings that seem to defy concise summarization. ${ }^{13}$ Even when the state exemption does not contain explicit language requiring that the exempt property be necessary for the debtor or his family, a debtor's attempt to use the bankruptcy exemptions to store wealth in assets that are highly liquid can still result in a denial of the exemption or even a denial of the discharge if the court feels that this was indicative of an attempt to "hinder, delay or defraud a creditor" (In re Armstrong, 97 B.R. 569, 570 (Bankr. Neb. 1989), aff'd 931 F.2d 1233, (8th Cir. 1991)). ${ }^{14}$

The vast majority of debtors do not maximize the theoretical exemption. This fact that many debtors who would apparently gain from these strategies neither file nor default, appear to suggest that the anti-abuse provisions are to some extent effective. ${ }^{15}$ This may help to explain the findings of White and Petropolous (1996) who note that far more bankruptcies should be observed given the nominal exemptions levels.

\section{3c. Other Consumer Credit Laws and Regulations}

It is important to remember that the mortgage creditor retains the right to foreclose if he is not repaid in full; the mortgage is senior to the exemption with respect to the home.

${ }^{12}$ In California, the exemption includes personal effects that are "ordinarily and reasonably necessary to, and personally used or procured for use by" the debtor or his family. Further, if an item has "extraordinary value" relative to that deemed necessary, the court can order the item sold and allow the debtor the "reasonable" portion of the proceeds.

${ }^{13} \mathrm{~A}$ good starting point for the interested reader is Collier on Bankruptcy.

${ }^{14}$ For related research, see Sieger, Vadner and Watkins (1994).

${ }^{15}$ As of 1981, the median asset value of bankrupt debtors in Illinois, Texas and Pennsylvania was $\$ 14,000$. In all three of these states, a couple in bankruptcy could have exempted more than this amount in the homestead alone (Sullivan, Warren and Westbrook (1989)). 
Moreover, the mortgage creditor is immune to several bankruptcy provisions which threaten other secured creditors or other lien-holders. For example, unlike other forms of secured credit, the mortgage is not split into secured and unsecured credit components by Section 506 and thus a debtor desiring to retain possession of his home must either convince the mortgage creditor to allow him to reaffirm the debt or pay the mortgage creditor in full. Likewise, the mortgage creditor is not affected by Section 1322(b)(2) which allows the debtor to reschedule payments in Chapter 13 according to a judicially determined interest rate. Finally, the debtor cannot make use of the lien avoidance provisions of section 522(f) for a mortgage contract.

Most of the states which have opted out of the federal exemptions have adopted state exemptions so generous that it appears a debtor is unlikely to choose the federal exemptions for reasons other than administrative convenience. Therefore, it is safe to say that state property exemptions are the dominant form of exemptions in bankruptcy. In addition, these exemptions continue to have significance outside of bankruptcy. Much like their operation in bankruptcy, a general creditor may only seize a debtor's property if the debtor has nonexempt equity in that asset. Again like bankruptcy, the exemptions do not affect the right of a creditor to seize his collateral if he is not repaid in full. Although the exemptions protect the debtor's assets equally whether or not he has filed, their value is enhanced by the discharge available in bankruptcy and the lien avoidance provisions of section 522(f). In the absence of bankruptcy, the debtors assets are only protected so long as they remain in exempt form. $^{16}$

Property exemptions are but one part of debtor/creditor law. Just as the exemptions vary across states, there is a fair amount of state-level variation in other aspects of the law which could directly affect the price and quantity of credit. A few examples will illustrate this problem. Texas significantly limits the ability of the debtor to grant a second mortgage

${ }^{16}$ Some exemptions protect the proceeds from a sale of exempt property for a period in order to allow the debtor to convert the proceeds into another form of exempt property. See, for example, HI Rev Stat 36-651-96. 
on his home through the very same statutes which create the exemptions. ${ }^{17}$ California prohibits mortgage lenders from seeking recourse against their debtors if foreclosure fails to generate sufficient assets to satisfy the debt. Several other states allow a debtor (or junior creditor) to redeem the home even after it has been sold at an auction. In addition, the states have adopted varying restrictions on the ability of a creditor to garnish his debtors wages.

While the above statutes are potentially measurable, they are beyond the scope of this paper. Rather than attempt to specify all legal and cultural variables that might affect the credit market, we rely on the use of cross-sectional and time series variation to control for some of these unmeasured effects. ${ }^{18}$

\section{Property Exemptions and Mortgage Credit}

In this section, we discuss the possible effects of increases in bankruptcy exemptions on the market for mortgage loans. In discussing bankruptcy exemptions, we distinguish between the homestead exemption and personal property exemptions.

\section{4a. Effects on the Demand for Mortgages}

For all of the reasons discussed above, we believe that the effect of the exemptions on the demand for mortgages is likely to be limited. Any discussion of the effect on the demand for secured credit must first acknowledge the fact that many debtors simply have no idea what the property exemptions are in their state at the time they enter into their loan contracts.

As with bankruptcy, the vast majority of the literature on secured credit is set in the context of the firm. However, the notion that secured and unsecured credit may serve, to some extent, as substitutes has clearly emerged (e.g., Schwartz (1997)). The degree of

\footnotetext{
${ }^{17}$ That is, creditors are not allowed to seize a homestead in Texas in or out of bankruptcy unless they hold a first mortgage, a "mechanics" lien (a home-improvement loan made on good faith), or a second mortgage issued for the improvement of the home. At present, Texas is considering lifting the ban on home equity loans.

${ }^{18}$ If omitted legal variables changed at the same time as the exemptions levels, our results would be biased. At least for wage garnishment laws, however, we know that almost no changes took place during our sample period.
} 
substitution will depend on the relative transactions costs of the two forms of credit, the relative ability of the creditors to monitor the debtor's actions and the ability of the unsecured creditors to observe the level of secured credit. For now, we note that it is unlikely that a shift in demand would affect the credit market unless it changed the type of debtor that applied for the loan. In addition, if capital is mobile across states so that supply is flat in any one state, demand shifts will not affect equilibrium terms of credit. Because the HMDA data set provides detailed information on the individuals who apply for the loan, we are able to control for this potential problem to a certain extent.

\section{4b. Effect on Supply}

To the extent that property exemptions do affect the market for home mortgage loans, we expect the effect to change the supply of mortgages. Our primary conclusion is that, unlike the supply of unsecured credit, the supply of mortgages should not be adversely affected by large homestead exemptions. Moreover, it is plausible that large homestead exemptions will increase the supply of mortgages.

Consider first the case of no transactions costs. The mortgage lender might take a negative view of personal property exemptions. This occurs because, if the mortgage lender cannot fully satisfy her claim by seizing the house, she would like to go after personal property. Large personal property exemptions prevent this. However, the mortgage creditor should be completely indifferent toward the homestead exemption as it will not affect his right to foreclose on the home if not paid in full. While somewhat obvious, we believe that this point has been overlooked in the literature and has important empirical implications.

With potential transactions cost, the situation is different. Specifically, assume that the home mortgage lender will incur some non-reimbursable costs if there is a forced sale of the debtor's home. Larger exemptions may induce the debtor to choose to file for bankruptcy and default on his unsecured loans thereby increasing the debtor's wealth. In addition, a larger homestead exemption may reduce the required repayment in a Chapter 13 bankruptcy again leading to a wealth effect. These wealth effect may prevent a default and save the lender the non-reimbursable costs. Larger homestead exemptions may also induce the debtor

to choose Chapter 7 over Chapter 13. We argue below that Chapter 7 is likely to pose lower 
costs for the home mortgage lender. A larger homestead exemption will make it less likely that there will be a foreclosure sale.

Larger personal property exemptions may have a beneficial effect because of the wealth effect. That is, if a debtor reaffirms the mortgage, the mortgage holder benefits from larger exemptions as they make the debtor wealthier and hence better able to continue to meet the payments. However, this must be balanced against the effect on the deficiency judgment and the debtor's incentives to engage in pre-bankruptcy planning; the mortgage creditor may prefer the debtor to have a large homestead exemption and small personal property exemption to encourage him to repay his mortgage before filing for bankruptcy. Therefore, the effect of the personal property exemptions is theoretically uncertain.

To evaluate these potential effects more explicitly, we employ a model in which we first focus on the debtor's choices of whether or not to repay his loans and whether or not to file for bankruptcy. Once this is specified we focus on the return to the mortgage lender.

\section{The Debtor's Decision}

Although the majority of papers addressing property exemptions have focused on the filing decision, no clear model of the debtor's filing decision has emerged. While we do not seek to fill this void here, we do need to address the issue in order to examine the effect of the exemptions on the return of the secured creditor. We assume that the debtor will have four general alternatives: repay all of his creditors in full, default on his unsecured loans and force the creditors to use state collections proceedings, file under Chapter 7 or file under Chapter 13 of the bankruptcy code. ${ }^{19}$ We assume throughout that the debtor may only keep his home if he repays his mortgage creditor in full; the mortgage creditor will not renegotiate the mortgage.

There are several reasons why the probability of filing for bankruptcy should depend on the exemptions. First, the exemptions may be larger in bankruptcy than in simple default.

\footnotetext{
${ }^{19} \mathrm{We}$ do not consider the choice of defaulting on the mortgage and repaying the unsecured loans. Because we assume that the mortgage lender has the right to a deficiency judgment, he has the right to be treated equally as the unsecured creditors.
} 
For example, some states allow filers to use the federal bankruptcy exemptions which may be larger than the state exemptions. In addition, some states, such as California have state exemptions that apply only in bankruptcy. Most importantly, bankruptcy permanently discharges debts and avoids certain liens. As a result, after bankruptcy the debtor is able to convert his exempt wealth into any form he likes without fear of seizure by creditors. He will no longer have to fear attachment by general creditors and those liens which were attached before bankruptcy. ${ }^{20}$ Rather than trying to be more explicit about the decision to file, we assume that the debtor will file with some probability that depends on the level of garnishment permitted, the exemptions, the value of his home and the value of his human capital, $b\left(g, X_{h}, X_{P}, h, k\right)$, where $g$ is the fraction of future income which is exempt from garnishment, $\mathrm{X}_{\mathrm{h}}$ and $\mathrm{X}_{\mathrm{P}}$ are the homestead and personal property exemptions, $\mathrm{h}$ is the value of the house and $\mathrm{k}$ is the debtor's human capital (equivalently, future income). ${ }^{21}$ Note that some of the anti-abuse provisions of the bankruptcy code may deny the debtor access to bankruptcy. In these circumstances the probability of filing is simply zero.

To simplify notation, throughout the discussion we assume that the personal property exemption is binding, $\mathrm{P}>\mathrm{X}_{\mathrm{P}}$, where $\mathrm{P}$ is personal property. The distressed debtor's exempt personal property is thus always equal to $\mathrm{X}_{\mathrm{P}}$. This assumption has no effect on the model's implications for changes in $X_{h}$. However, without this assumption, marginal changes to $X_{P}$ may have zero effect on the lender.

${ }^{20}$ Some state exemptions allow attachment of the debtor's property even though they do not allow foreclosure and sale of the property. For example, Section 41.001 of the Texas Property Code only explicitly prohibits the "seizure [of a homestead] for the claims of creditors." This language has resulted in some ambiguity. Some courts have held that no lien can attach the homestead. Hoffman v. Love, 494 S.W.2d 591, 593-94 (Tex. Civ. App.Dallas 1973), writ ref'd n.r.e. per curiam 499 S.W.2d (Tex. 1973); Harms v. Ehlers, 179 S.W.2d 582, 583 (Tex. Civ. App.-Dallas 1944, writ ref'd). However, other, more recent, cases have found that an unenforceable lien attaches. See Exocet, Inc. v. Cordes, 815 S.W.2d 350 (Tex. App.- Austin 1991, no writ.) These liens may, however, "place a cloud on the debtor's title" and thus are avoidable in bankruptcy." In re Henderson, 18 F.3d 1305, $1310-11$ ( $5^{\text {th }}$ Cir. 1994).

${ }^{21}$ The federal garnishment exemption is the greater of $75 \%$ or thirty times the minimum wage per week. 


\section{Default outside Bankruptcy}

Consider a debtor who decides not to repay his unsecured creditors but does not file for bankruptcy. His unsecured creditors (including the mortgage creditor if there is a deficiency judgment) will have the right to garnish his wages and seize any non-exempt property in satisfaction of their debt. In order to retain his home, the home equity (plus subjective value) must be worth more than the debt but not so valuable that the equity exceeds $X_{h}$. If the equity exceeds $X_{h}$, any creditor can demand the excess equity and thereby force a sale of the house. If the value of the home (including the subjective value) is less than the value of the mortgage, a debtor defaulting on his unsecured debt would have no reason to repay his mortgage. That is, he will retain his home if $\mathrm{M}-\mathrm{v}<\mathrm{h}<\mathrm{M}+\mathrm{X}_{\mathrm{h}}$, and $\mathrm{gk}+\mathrm{X}_{\mathrm{P}}>\mathrm{M}$, where $\mathrm{v}$ is the subjective value of the home and $\mathrm{M}$ is the amount of the mortgage loan.

\section{Chapter 7}

Now consider a debtor filing under Chapter 7. The mortgage creditor must be repaid in full if the debtor is to retain the home. The debtor may only do so if he has sufficient assets, other than the home, to repay the debt in full, $\mathrm{k}+\mathrm{X}_{\mathrm{P}}>\mathrm{M}$. By filing for bankruptcy the debtor has more wealth available for repayment as he is no longer subject to garnishment or the other pressures that the unsecured creditors can place on a delinquent debtor. As with simple default, the equity must be enough to make reaffirming the mortgage rational but not so much that it exceeds the exemption, $\mathrm{M}-\mathrm{v}<\mathrm{h}<\mathrm{M}+\mathrm{X}_{\mathrm{h}}$. If both of these conditions are met, the debtor's consumption is $\mathrm{X}_{\mathrm{P}}+\mathrm{h}-\mathrm{M}+\mathrm{v}+\mathrm{k}-\mathrm{T}_{7}$ where $\mathrm{T}_{7}$ represents the debtor's transactions costs in Chapter 7. If one of these conditions is not met, the debtor will lose his home in a chapter 7 bankruptcy and his wealth will be $\mathrm{X}_{\mathrm{P}}+\operatorname{Min}\left[\mathrm{X}_{\mathrm{h}}, \mathrm{h}-\mathrm{M}\right]+\mathrm{k}-\mathrm{T}_{7}$.

The transactions costs of Chapter 7 are likely to be much different than those of default outside of bankruptcy and their size is likely to depend on the individual characteristics of the debtor and the community in which he lives. The debtor will have to pay a filing fee and may need to hire a lawyer. In addition, the debtor may face an additional stigma beyond what he would have faced had he simply defaulted. However, the automatic stay will protect the debtor from unwanted collections calls and the anti-discrimination 
provision of Section 525 may provide some comfort as well. From a theoretical level it is unclear whether a bankruptcy appears worse or better on the debtor's credit record than default in the absence of bankruptcy. If a debtor files for Chapter 7 he will be unable to do so again for six years. This has lead some scholars to assert that bankrupt debtors are good credit risks. $^{22}$ However, a bankruptcy filing may signal a greater willingness to use legal mechanisms to avoid repayment. The threat of other legal mechanisms certainly exists. ${ }^{23}$

\section{Chapter 13}

The debtor may also file for bankruptcy under Chapter 13. Under Chapter 13 the debtor is permitted to retain all of his physical assets, including his non-exempt property, but must in return pay some of his future earnings. Two important considerations arise. First, the creditors must receive at least as much as they would have received in a Chapter 7 filing. Therefore the debtor must pay at least $\left(\mathrm{P}-\mathrm{X}_{\mathrm{P}}\right)+\mathrm{Max}\left[0, \mathrm{~h}-\mathrm{M}-\mathrm{X}_{\mathrm{h}}\right]$ to his unsecured creditors. Second, the debtor must pay all of his "disposable income." This second provision may be less strict than it would appear. Basically, this provision provides that the debtor's budget may not contain "luxuries unavailable to the average American." 24 We will assume that the additional amount depends on the value of his future earnings, $R_{13}(k)$.

As always, the mortgage creditor must be repaid if the debtor is to keep the home. In addition, the unsecured creditors can seize the home if the debtor does not pledge sufficient income to offset any non-exempt equity. Therefore, in order to retain the home the debtor must repay at least $\mathrm{P}-\mathrm{X}_{\mathrm{P}}+\operatorname{Max}\left[\mathrm{M}, \mathrm{h}-\mathrm{X}_{\mathrm{h}}\right]+\mathrm{R}_{13}(\mathrm{k})$.

\footnotetext{
${ }^{22}$ For example, Frank (1996) reports, "Prof. Warren says some credit-card issuers actually review bankruptcy filings in search of potential customers. Their logic is simple: the law doesn't allow people to file for [a Chapter 7] bankruptcy more than once every six years. Thus, the recently bankrupt are, in some sense, perfect debtors - they can't just walk away from their debts."

${ }^{23}$ Less well-know but powerful methods of shielding assets include spendthrift trusts or the doctrine of Tenancy by the Entirety. A brief discussion of these methods can be found in Hynes (1998).

${ }^{24}$ Collier's 1325-53, 1325.08[4](b) citing In re Tinneberg, 59 B.R. 634 (Bankr. E.D. NY 1986); In re Hedges, 68 B.R. 18 (Bankr. E.D. VA. 1986).
} 
Depending on the debtor, the transactions cost of chapter 13 may or may not be greater than the costs of chapter 7. The debtor will likely have greater legal fees in a Chapter 13 proceeding as the process is longer and more complicated. However, there may be less moral stigma attached to a Chapter 13 filing as there is an effort to repay out of future earnings and presumably a larger payment. One may also assert that a Chapter 13 filing will do less damage to the individual's credit rating. However, at this time most credit agencies do not distinguish between a Chapter 7 and a Chapter 13 filing. In addition, a debtor who has filed under Chapter 13 may file under Chapter 7 without waiting six years.

The foregoing discussion suggests one immediate conclusion. The debtor will always have to make greater payments in Chapter 13 than in Chapter 7. Therefore, assuming that the transactions costs of Chapter 13 are at least as high as Chapter 7, a debtor would only file under Chapter 13 if, by doing so, he can keep his house. This occurs when his equity position is above the legal exemption and his future income is high enough to meet the Chapter 13 payments, $h>M+X_{h}$ and $k>h-X_{h}-X_{P}+R_{13}$.

\section{Repayment}

If the debtor repays his unsecured creditors his return is simply $h+v+k-U-M$. Given the above, it is clear that his filing decision will depend on the value of his home, his human capital, the exemptions, the garnishment limitation and the relative tranasactions costs. We define $K_{D}\left(h, X_{h}, X_{P}, g, R_{13}\right)$ as the level of human capital above which the debtor will repay his creditors in full.

\section{The Return to Mortgage Lender}

In a world without transactions costs, the size of the homestead exemption would have no effect on the return to the home mortgage lender. The home mortgage lender is senior to the exemption. However, a mortgage creditor is likely to face non-trivial transactions costs when dealing with distressed debtors. We consider three distinct forms of transactions costs. The first are foreclosure costs such as lawyers fees and running an auction. The creditor is entitled to reimbursement for these costs from the proceeds of the sale and we denote these costs $\mathrm{Q}_{7}$ when foreclosure occurs in Chapter 7 and $\mathrm{Q}_{\mathrm{n}}$ when it occurs outside of bankruptcy. 
It is likely that $\mathrm{Q}_{7}<\mathrm{Q}_{\mathrm{n}}$. It is true that bankruptcy may delay foreclosure. However, this delay is unlikely to be long and a fully secured mortgage lender is entitled to interest payments. $^{25}$ Some have asserted that bankruptcy provides a better system for foreclosure and sale. For example, Lopucki (1991) argues that bankruptcy provides better mechanisms for gaining information on the debtor in order to determine whether to foreclose, makes it easier to prevent abuse of the property, allows for liquidation free and clear of other liens, cuts-off the "right of redemption" (which allows the debtor to make good on the mortgage for up to 6 months), and allows the lender to bypass state anti-deficiency legislation.

The creditor is also likely to face non-reimbursable costs whenever legal proceedings result. In a bankruptcy proceeding the debtor voluntarily surrenders his property making the difficult and risky process of foreclosure unnecessary. In addition, the debtor has an incentive to comply with the legal proceedings in order to secure his discharge. Even in the absence of a foreclosure, these costs within bankruptcy are not likely to be much higher than under state collections proceedings. The debtor has chosen to reaffirm the debt and will make the payments on a regular schedule. Therefore, the mortgage creditor need not participate heavily in the process. In fact, many debtors do not even list their mortgage creditor making their participation completely unnecessary (e.g., Sullivan, Warren, and Westbrook (1989))

Other significant non-reimbursable costs are those associated with continuing a debt contract with a recently distressed debtor. These costs are taken to be inversely proportional to wealth. The costs incurred by the mortgage lender are summarized in the first row of Table 1. Unless the relationship with the debtor is ended through foreclosure, costs are a function of the debtor's wealth.

Rows 2-4 of Table 1 show the returns to the lender from mortgage payments, foreclosure sales and from deficiency judgements (when the debt cannot be covered by sale of the home). The mortgage lender gets a fraction of the debtor's property from a deficiency judgement; the fraction is equal to the housing debt divided by total debt. The bottom row indicates the net return for each possible debtor action, with $F_{7}(h)$ and $F_{n}(h)$ denoting the

\footnotetext{
${ }^{25}$ Elias, Renauer and Leonard (1995) describe delays on the order of an additional month.
} 
returns from foreclosure and deficiency.

As mentioned above, we allow the debtor's decision to repay all of his debts to depend on the level of garnishment allowed, the exemptions, the value of his home and the value of his human capital. Full repayment will occur when $k>K_{D}\left(g, X_{p}, X_{h}, h\right)$.

Let $f(h)$ and $j(k)$ represent the densities of $h$ and $k$, respectively. Suppressing the dependence of $\mathrm{b}$ on $\mathrm{X}_{\mathrm{p}}, \mathrm{X}_{\mathrm{h}}, \mathrm{g}, \mathrm{h}$, and $\mathrm{k}$ for notational simplicity, the mortgage creditor's expected return can be now written as follows:

$$
E(R)=\int_{h=0}^{M-v}\left(\int_{k=0}^{K_{d}\left(X_{h^{\prime}}, X_{p}, g, h\right)}\left(\left(b\left(F_{7}-C_{7 f}\right)+(1-b)\left(F_{n}-C_{n f}\right)\right) j(k) d k+\int_{k=K}^{k=K} M-K_{d}(k-U-M) j(k)\right)\right) f(h) d h+
$$

$\int_{h=M-v}^{M+X_{h}}\left(\int_{k=0}^{M-X_{p}}\left(b\left(F_{7}-C_{7 f}\right)+(1-b)\left(F_{n}-C_{n f}\right) j(k) d k+\int_{k=M-X_{p}}^{\left(M-X^{p} / g\right.}\left(b\left(M-C_{7 r}\left(k+X_{p}-M\right)\right)+(1-b)\left(F_{n}-C_{n f}\right) j(k) d k\right) f(h) d h+\right.\right.$

$\int_{h=M-v}^{M+X_{h}}\left(\int_{k=\left(M-X_{p}\right) / g}^{K_{d}}\left(b\left(M-C_{7 r}\right)+(1-b)\left(M-C_{n r}\left(g k+X_{p}-M\right)\right) j(k) d k+\int_{k=K_{d}}^{K}\left(M-C_{r}\right) j(k) d k\right) f(h) d h+\right.$

$$
\int_{h=M+X_{h}}^{H}\left(\int_{k=0}^{h-X_{h}-X_{p}}\left(b\left(F_{7}-C_{7 f}\right)+(1-b)\left(F_{n}-C_{n f}\right)\right) j(k) d k+\right.
$$

$\int_{k=h-X_{h}-X_{p}+R_{13}}^{K_{d}}\left(b\left(M-C_{13}\left(k+X_{p}+X_{h}-h-M-R_{13}\right)\right)+(1-b)\left(M-C_{n f}\right) j(k) d k+\int_{k=K}^{K}\left(M-C_{d}(k-U)\right) j(k) d k\right) f(h) d h$

In order to determine the effect of an increase in the homestead exemption, we need only evaluate the sign of the derivative of the return with respect to $X_{h}$. First we make the 
following assumptions about the magnitude of relative transactions costs.

\section{Assumption 1}

Foreclosure is less costly under court supervision, $\mathrm{C}_{7 \mathrm{f}}<\mathrm{C}_{\mathrm{nf}}$.

\section{Assumption 2}

Reaffirmed mortgages are less costly than foreclosures, $\mathrm{C}_{13}<\mathrm{C}_{\mathrm{nf}}, \mathrm{C}_{13}<\mathrm{C}_{7 \mathrm{f}}, \mathrm{C}_{7 \mathrm{r}}<\mathrm{C}_{7 \mathrm{f}}$ and $\mathrm{C}_{\mathrm{nr}}$ $<\mathrm{C}_{\mathrm{nf}}$.

\section{Assumption 3}

Mortgage lenders prefer that the debtor file under Chapter 13 and thereby partially discharge the unsecured debt rather than repay the unsecured debt in full, $\mathrm{C}_{13}<\mathrm{C}_{\mathrm{r}}$. The partial discharge increases the wealth of the debtor.

\section{Assumption 4}

Defaulting debtors with non-exempt equity in their home and a relatively high value of human capital are likely to file under Chapter 13 to avoid foreclosure; $b\left(g, X_{h}, X_{P}, h, k\right)$ is close to one in this region.

\section{Lemma 1}

Under assumptions 1-4, the expected mortgage return to the lender is increasing in the homestead exemption, $\frac{\partial \mathrm{E}(\mathrm{R})}{\partial \mathrm{X}_{\mathrm{h}}}>0$.

\section{Proof}

See Appendix 1.

\section{Lemma 2}

Under assumptions 1-4, the effect of marginal increases in personal property exemptions are theoretically ambiguous. Specifically, they will depend on the relative magnitudes of the beneficial wealth effect on the debtor versus the detrimental effect of the 
decreased ability to seize the debtor's personal property (deficiency judgements). That is, the sign of $\frac{\partial E(R)}{\partial X_{p}}$ is theoretically indeterminant.

Proof

See Appendix 1.

Lemma 1 immediately suggests that a correlation between homestead exemptions and favorable supply conditions should be empirically detectable. Following Stiglitz and Weiss (1981), Longhofer (1996), and Williamson (1986, 1987), we note that a shift in the supply of credit may manifest itself in reduced credit rationing or lower interest rates. Intuitively, changes to the interest rate may not necessarily clear the market because they have effects on the type of loan and the probability of repayment. For example, higher interest rates will 1) decrease the ability of a given debtor to repay; 2) change the pool of applicants by decreasing the number of high quality applicants and 3) cause some debtors to engage in riskier behavior. Longhofer (1996) explicitly examines the effect of exemptions on the probability of denial in a costly state verification model. He shows that if one considers credit generally, larger exemptions should lead to greater credit rationing as the creditors cannot make up for the reduced return in default by increasing the interest rate.

This result is not robust to the inclusion of secured credit. It is unlikely that homestead exemptions will reduce the return to the mortgage lender when the debtor is in financial distress. Indeed, lemma 1 implies that larger homestead exemptions should lead to lower interest rates and reduced credit rationing. However, it is possible that personal property exemptions will increase credit rationing.

\section{Empirical Tests and Results}

We first investigate whether the probability of being denied credit, in the form of a mortgage, is increasing in the homestead or personal property exemption level. The Home Mortgage Discrimination Act (HMDA) data contains a summary of every mortgage application taken by qualifying mortgage lenders in the United States from 1990-1995. Because of the enormity of this data set (about 3.8 million in 1995 alone), we select a random 
subset of approximately 100,000 observations per year. We exclude FHA, VA and Farmers' Home Administration loans. We also exclude home improvement loans. Each application includes the income, race, sex, and state of residence of the applicant and co-applicant (if any) as well as the size of the loan requested and the decision of whether the application was accepted or rejected.

We study probability of denial by estimating a logit regression of the form:

$$
\mathrm{y}_{\mathrm{it}}=\alpha_{\mathrm{i}}+\beta_{1} \mathrm{X}_{\mathrm{h}, \mathrm{it}}+\beta_{2} \mathrm{X}_{\mathrm{p}, \mathrm{it}}+\gamma \mathrm{Z}_{\mathrm{it}}+\varepsilon_{\mathrm{it}}, \quad \mathrm{y}_{\mathrm{it}}=(0,1),
$$

where $y_{i t}=1$ for denied and 0 for approved. $Z_{i t}$ is a vector of individual characteristics including income, income squared, race, marital status as well as the state unemployment rate as a proxy for regional business cycle conditions (taken from the Selective Access Service of the Bureau of Labor Statistics).

We assume that the exemption of interest is that available to a debtor who does not qualify for special treatment due to age, infirmity, veteran's status or occupation. Because our analysis predicts that the homestead and personal property exemptions may have very different implications, we construct two measures. First, we construct a measure of the homestead exemption which includes the amount of equity a debtor may exempt as well as any wildcard exemption which may be used on the home. We ignore any limitations on the lot size. This measure is relatively straightforward to calculate. In addition, we construct a measure for the personal property exemptions which again includes any wildcard exemption as well as the equity in a car that a debtor may exempt and the amount of jewels that a debtor may keep other than wedding and engagement rings. ${ }^{26}$ Perhaps surprisingly, the two exemptions categories are statistically uncorrelated, with a point estimate of -0.05 .

Given this data, we construct both continuous and dummy variables. If a state has an "unlimited" exemption, we set the exemption variable equal to one million dollars in the

\footnotetext{
${ }^{26}$ Numerous states have unlimited exemptions for wedding and engagement rings.
} 
continuous analysis. ${ }^{27}$ We express the continuous variables in units of $\$ 100,000$. Our second approach, following GSW, is to group the exemption levels into quartiles with the fourth quartile containing only those states with unlimited exemptions.

We do not make the dubious assumption -- implicit in pooled regressions -- that there are no systematic differences in credit denials, except those related to the regressors. Because states are likely to experience other differential influences (e.g., cultural and legal), we estimate a fixed-effects model which allows the intercept to vary across states (at the cost of a reduction in degrees of freedom).

Table 2 presents maximum likelihood estimates based on the continuous specification of the homestead exemption. Columns 2 to 4 show the coefficients, standard errors and pvalues allowing for fixed state effects. The coefficients on the fixed state effects are omitted from the table. The fifth column of the table, labeled standardized estimate, reports the coefficient estimate normalized by the variance.

As predicted by lemma 1, the coefficient on the homestead exemption is significantly negative. The signs of the coefficients associated with the other variables are consistent with what we would expect. The probability of denial appears to decrease with higher incomes, and increases for higher state unemployment rates and larger loan requests. African-american applicants appear to have a higher probability of denial, as do single applicants. The dummy variable for female applicants should be interpreted with caution as this indicates only that the primary applicant was female. Four of five annual dummies are significantly different from zero, suggesting that the overall probability of denial changes markedly from year to year.

Table 3 shows the results based on grouping the homestead exemption into quartiles. Again, the quartiles take the expected negative sign implying that larger exemptions lead to a lower probability of denial as the mortgage lenders prefer large homestead exemptions.

In Table 4, we include the personal property exemption in addition to the continuous homestead. The coefficient on the homestead exemption is little altered, remaining significantly negative. However, the personal property exemptions are positively correlated

\footnotetext{
${ }^{27}$ The results in this paper were not sensitive to alternative ceilings such as two million dollars.
} 
with the probability of denial, although only at a significance level of $75 \%$.

It is possible that the negative coefficient on the homestead exemption is a result of simultaneity bias in the selection of the exemptions -- states with more restrictive credit markets may choose lower exemptions. Nevertheless, even if this interpretation were accurate, any negative effect that the homestead exemption has on the supply of mortgages is insufficient to overcome the effect of this bias.

We also examine whether, as we have suggested, large bankruptcy exemptions tend to drive down mortgage rates (presumably by encouraging supply). We use annual mortgage rates available to borrowers in each of the 50 states and the District of Columbia. These data are taken from Rates \& Terms on Conventional Home Mortgages, 1995 compiled by the Federal Housing Finance Board.

The coefficient estimates from fixed-effects panel regressions are shown in Tables 5. The top panel of Table 5 reports coefficient estimates from a fixed-effects panel data regression of mortgage rates on the homestead exemption, the unemployment rate and average hourly wage rate from the Selective Access Service, annual dummies and the two demographic variables, percentage African-american and percentage senior citizen. ${ }^{28}$ Consistent with our hypothesis that supply has increased, the homestead exemption variable enters negatively with a t-statistic of -1.5 or a confidence level of about $87 \%$. Personal property exemption enter insignificantly. An Ftest of the joint significance of the random effects indicates a p-value of .00 , suggesting strong evidence in favor of differential state effects. In addition, we calculated the Hausman (1978) specification test of random effects model against the alternative of the fixed-effects model. The associated p-value is .52 which indicates no evidence in favor of either.

The lower panel of Table 5 replicates the analysis for the loan-to-value ratio. Although not significant, it is interesting to note that the coefficient on the personal property exemption is -1.1. This is consistent with the estimation of the probability of denial; it is plausible that the personal property exemptions reduce the supply of mortgage loans.

Quite apart from whether bankruptcy exemptions exert a statistically significant effect

\footnotetext{
${ }^{28}$ Demographic data are available on the internet at http://www.census.gov/.
} 
on credit conditions, are they economically important? Table 6 presents fitted values from the logit regression for typical debtors in four states. The middle panel shows estimated probabilities of denial for white, married consumers in low, middle and high income brackets and median loan-to-income ratios in $1995 .{ }^{29}$ South Carolina and Delaware are shown in columns 4 and 5. Delaware's exemptions are about twice that of South Carolina. At the same time, the implied probability of denial for South Carolinians is $10 \%$ to $15 \%$ higher - a substantial difference. Column 6 shows fitted values for West Virginia which has higher homestead and personal property exemptions compared to Delaware. Given our estimates, denial is noticeably more likely in West Virginia than in Delaware for each income bracket. In Mississippi which allows a homestead exemption ten times that of West Virginia, we estimate that denial is over $10 \%$ less likely. Of course, these differences cannot be solely attributed to the exemption levels. The predicted state denial rates condition on fixed state effects which may reflect other cultural and legal variables.

In order to focus on the importance of exemptions in isolation, the bottom panel of Table 6 reports the percentage difference that would be predicted from quadrupling either the homestead or personal property exemption. Clearly, the economic impact from increasing the homestead exemption is small in states with currently small exemptions. This becomes especially apparent when compared to the estimated increase in the probability of denial from quadrupling personal property exemptions.

Turning to mortgage rates, Table 7 shows estimated terms on fixed rate mortgages typical consumers in the same four states. Again the lower panel displays the implied percentage change in the dependent variables that would result from quadrupling either exemption category. As with denial rates, large increases to the homestead exemption imply relatively small changes, less than $1 \%$, to mortgage rates and down payments. A fourfold increase in personal property exemptions, yields mortgage rate and down payment increases in the range of 1 to 5 percent. However, it should be noted that the loan-to-value ratio regressions indicated that these changes are not statistically significant.

\footnotetext{
${ }^{29}$ Income levels are defined as less than $\$ 24,999$, between $\$ 25,000$ and $\$ 49,999$, and more than $\$ 50,000$. Each income category contains roughly one third of U.S. families.
} 
On balance, the changes in exemption levels are associated with relatively small changes in the probability of denial and mortgage rates. Nevertheless, these results confirm the essential theme we have outlined -- the mortgage lender is unlikely to be adversely affected by a large homestead exemption.

\section{Conclusion}

Existing research into bankruptcy property exemptions have found significant adverse consequences for consumer credit markets, raising interest rates and reducing access to credit. We find that these results do not hold for the homestead exemption and the mortgage loan market. Indeed, the probability of being turned down on a mortgage application appears to be (marginally) lower for residents of states with high homestead exemption levels. In addition, mortgage rates appear to be lower in states with high homestead exemption levels. The results are reversed if one considers the personal property exemptions.

The discrepancy between the results of our paper and those of the previous research may result from the important differences between secured and unsecured credit. More research is necessary to determine the effects of property exemptions on purely unsecured and undersecured credit. Such research is particularly needed in light of the recent renewed calls for standardized federal bankruptcy exemptions.

The National Bankruptcy Review Commission conducts a periodic review of the bankruptcy process creating the possibility that academic research could lead to significant reform. Despite the apparent need for research on personal bankruptcy, the number of academic papers on this topic is quite limited when compared to the literature on its more seductive cousin, the Chapter 11 reorganization. We hope that this paper, to our knowledge the first to study the effects of personal bankruptcy on mortgages, motivates additional research in this area. 


\section{References}

Apilado, V. P., J. J. Dauten, and D. E. Smith, (1978), "Personal Bankruptcies," Journal of Legal Studies, 7, 371-393.

Avery, R. B., G. E. Ellihausen and A. B. Kennickell (1988), "Measuring Wealth with Survey Data: An Evaluation of the 1983 Survey of Consumer Finances," Review of Income and Wealth, 34, 339-369.

Boyes, W. J. and R. L. Faith (1986), "Some Effects of the Bankruptcy Reform Act of 1978," Journal of Law and Economics, 24, 139-149.

Buckley, F. H. and M. F. Brinig (1996), "The Bankruptcy Puzzle," George Mason University Working Paper, no. 21.

Domowitz, I. and T. L. Eovaldi, (1993), “The Impact of the Bankruptcy Reform Act of 1978 on Consumer Bankruptcy," Journal of Law and Economics, 36, 803-835.

Eisenberg, T. (1981), "Bankruptcy Law in Perspective," UCLA Law Review, 28, 953.

Elias, S., A. Renauer and R. Leonard (1995), How to Declare Personal Bankruptcy. Berkeley, California: Nolo Press.

Frank, S. E. (1996), “Over Your Head in Debt? Bankruptcy Offers New Start”, Wall Street Journal, C1, August 23.

Gropp, R., J. K Scholz and M. White (1997), "Personal Bankruptcy and Credit Supply and Demand," Quarterly Journal of Economics, 1, 217-251.

Hausman, J. (1978), "Specification Tests in Econometrics," Econometrica, 46, 69-85.

Hynes, R. M. (1997), "Property Exemptions and the Bankruptcy Filing Rate: A Reexamination of the Simple Hypothesis," manuscript, University of Chicago.

Hynes, R. M. (1998), Three Essays on Property Exemptions, Doctoral Dissertation, University of Pennsylvania.

Kennickell, A. B. and M. Starr-McCluer (1994), "Changes in Family Finances from 1989 to 1992: Evidence from the Survey of Consumer Finances," Federal Reserve Bulletin, 80, 861-882. 
Kennickell, A. B., M. Starr-McCluer and A. E. Sunden (1997), "Family Finances in the United States: Recent Evidence from the Survey of Consumer Finances," Federal Reserve Bulletin, 83, 1-24.

Longhofer, S. D. (1996), "A Note on Absolute Priority Rule Violations, Credit Rationing, and Efficiency," manuscript, Federal Reserve Bank of Cleveland.

Lopucki, L. M. (1991) Strategies for Creditors in Bankruptcy Proceedings. Boston, Massachusetts: Little, Brown.

Modigliani, F. and M. H. Miller, (1958) "The Cost of Capital, Corporation Finance and the Theory of Investment", American Economic Review, 48, 261-275.

Peterson, R. and Aoki, K. (1984), "Bankruptcy Filings Before and After Implementation of the Bankruptcy Reform Law," Journal of Economics and Business, 36, 95-105.

Rea, S. A. (1984), "Arm Breaking, Consumer Credit and Personal Bankruptcy, Economic Inquiry, 22, 188-208.

Schwartz, A. (1981), "Security Interests and Bankruptcy Priorities: A Review of Current Theories," Journal of Legal Studies, 10, 1-37.

Schwartz, A. (1997), "Priority Contracts and Priority in Bankruptcy," manuscript, Yale University Law School.

Shiers, A. F. and D. P. Williamson (1987), "Nonbusiness Bankruptcies and the Law: Some Empirical Results, Consumer Affairs, 21, 277-290.

Sieger, S. E., M. Vadner and B. Watkins (1994), "Survey: Fraud as an Impediment to Discharge - denial of Discharge and Exceptions to Discharge under the Bankruptcy Code," Journal of Bankruptcy Law and Practice, 3, 469-546.

Sullivan, T. A. E. Warren and J. L. Westbrook (1989), As We Forgive Our Debtors: Bankruptcy and Consumer Credit in America. New York: Oxford University Press.

Sullivan, T. A. E. Warren and J. L. Westbrook (1994), "Consumer Debtors Ten Years Later: A Financial Comparison of Consumer Bankrupts 1981-1991," American Bankruptcy, 68, 121-139.

Welch, K. D. (1996), "Bankruptcy, Debtor's Prison and Collateral in Optimal Debt Contracts," manuscript. 
White, M. and W. Petropolous (1996), "Creditor's Remedies and Debtor's Right to file for Bankruptcy: Why don't more Households Go Bankrupt?" manuscript, University of Michigan.

White, M. (1987), "Personal Bankruptcy Under the 1978 Bankruptcy Code: An Economic Analysis," Indiana Law Journal, 63:1, 1-53. 
Table 1

Returns to the Mortgage Lender

\begin{tabular}{|c|c|c|c|c|c|c|}
\hline $\begin{array}{l}\begin{array}{r}\text { Debtor } \\
\text { Action }\end{array} \\
\text { Return to } \\
\text { Lender }\end{array}$ & $\begin{array}{l}\text { Chapter } 7 \\
\text { Foreclosure }\end{array}$ & $\begin{array}{l}\text { No Filing } \\
\text { Foreclosure }\end{array}$ & $\begin{array}{l}\text { Chapter } 7 \\
\text { Reaffirm }\end{array}$ & $\begin{array}{l}\text { No Filing } \\
\text { Reaffirm }\end{array}$ & Chapter 13 & $\begin{array}{c}\text { Full } \\
\text { Repayment }\end{array}$ \\
\hline Costs & $\mathrm{C}_{7 \mathrm{f}}$ & $\mathrm{C}_{\mathrm{nf}}$ & $\mathrm{C}_{7 \mathrm{r}}\left(\mathrm{k}+\mathrm{X}_{\mathrm{P}}-\mathrm{M}\right)$ & $\mathrm{C}_{\mathrm{NR}}\left(\mathrm{gk}+\mathrm{X}_{\mathrm{P}}-\mathrm{M}\right)$ & $\begin{array}{r}\mathrm{C}_{13}\left(\mathrm{k}+\mathrm{X}_{\mathrm{h}}\right. \\
\left.+\mathrm{X}_{\mathrm{P}}-\mathrm{h}-\mathrm{R}_{13}\right)\end{array}$ & $\mathrm{C}_{\mathrm{r}}(\mathrm{k}-\mathrm{U}-\mathrm{M})$ \\
\hline $\begin{array}{l}\text { Mortgage } \\
\text { Return }\end{array}$ & & & M & M & M & M \\
\hline $\begin{array}{l}\text { Foreclosure } \\
\text { Return }\end{array}$ & $\operatorname{Min}\left[\mathrm{h}, \mathrm{M}+\mathrm{Q}_{7}\right]-\mathrm{Q}_{7}$ & $\operatorname{Min}\left[h, M+Q_{n}\right]-Q_{n}$ & & & & \\
\hline $\begin{array}{l}\text { Deficiency } \\
\text { Judgement }\end{array}$ & $\begin{array}{c}\left(\mathrm{P}-\mathrm{X}_{\mathrm{P}}\right) \\
\operatorname{Max}\left[\mathrm{M}+\mathrm{Q}_{7}-\mathrm{h}, 0\right] \\
/\left(\mathrm{U}+\mathrm{Max}\left[\mathrm{M}+\mathrm{Q}_{7}-\mathrm{h}, 0\right]\right)\end{array}$ & $\begin{array}{c}\left((1-\mathrm{g}) \mathrm{k}+\mathrm{P}-\mathrm{X}_{\mathrm{P}}\right) \\
\operatorname{Max}\left[\mathrm{M}+\mathrm{Q}_{7}-\mathrm{h}, 0\right] \\
/\left(\mathrm{U}+\mathrm{Max}\left[\mathrm{M}+\mathrm{Q}_{7}-\mathrm{h}, 0\right]\right)\end{array}$ & & & & \\
\hline Net Return & $\mathrm{F}_{7}(\mathrm{~h})-\mathrm{C}_{7 \mathrm{f}}$ & $F_{n}(h)-C_{n f}$ & $\begin{array}{c}\mathrm{M}- \\
\mathrm{C}_{7 \mathrm{r}}\left(\mathrm{k}+\mathrm{X}_{\mathrm{P}}-\mathrm{M}\right)\end{array}$ & $\begin{array}{c}\mathrm{M}- \\
\mathrm{C}_{\mathrm{nr}}\left((1-\mathrm{g}) \mathrm{k}+\mathrm{X}_{\mathrm{P}}-\mathrm{M}\right)\end{array}$ & $\begin{array}{c}\mathrm{M}- \\
\mathrm{C}_{13}\left(\mathrm{k}+\mathrm{X}_{\mathrm{P}}+\mathrm{X}_{\mathrm{h}}-\mathrm{h}-\mathrm{R}_{13}\right)\end{array}$ & $\begin{array}{c}\mathrm{M}- \\
\mathrm{C}_{\mathrm{r}}(\mathrm{k}+\mathrm{P}-\mathrm{U}-\mathrm{M})\end{array}$ \\
\hline
\end{tabular}

Notes: Gross and net returns to the mortgage lender as a function of debtor action. See text for details. 
Table 2. The Probability of Being Denied Credit and the Homestead Exemption

\begin{tabular}{|c|c|c|c|c|c|}
\hline Variable & $\begin{array}{l}\text { Parameter } \\
\text { Estimate }\end{array}$ & $\begin{array}{l}\text { Standard } \\
\text { Error }\end{array}$ & $\begin{array}{c}\text { Wald } \\
\text { Chi-Square }\end{array}$ & P-Value & $\begin{array}{c}\text { Standardized } \\
\text { Estimate }\end{array}$ \\
\hline Constant & -1.5742 & 0.1877 & 70.300 & 0.0001 & \\
\hline Exemption & -0.0320 & 0.0001 & 13.019 & 0.0003 & -0.05907 \\
\hline Loan-to-Income Ratio & 0.0020 & 0.0008 & 6.5428 & 0.0105 & 0.01356 \\
\hline Year91 & 0.1183 & 0.0196 & 36.562 & 0.0001 & 0.02025 \\
\hline Year92 & -0.0737 & 0.0179 & 16.890 & 0.0001 & 0.01625 \\
\hline Year93 & -0.2096 & 0.0178 & 139.32 & 0.0001 & -0.05116 \\
\hline Year94 & 0.0218 & 0.0185 & 1.4004 & 0.2367 & 0.00463 \\
\hline Year95 & 0.2854 & 0.0179 & 252.85 & 0.0001 & 0.05807 \\
\hline Income & -0.3310 & 0.0001 & 1282.4 & 0.0001 & -0.26603 \\
\hline Income Squared & $3.6 \mathrm{e}-05$ & 0.0001 & 1079.5 & 0.0001 & 0.18689 \\
\hline Dummy for African-American & 0.7129 & 0.0176 & 1646.7 & 0.0001 & 0.07932 \\
\hline Dummy for Female & -0.0290 & 0.0122 & 5.6705 & 0.0173 & -0.00601 \\
\hline Dummy for Single & 0.2783 & 0.0105 & 700.56 & 0.0001 & 0.06775 \\
\hline Unemployment & 0.8114 & 0.3312 & 6.0012 & 0.0143 & 0.00712 \\
\hline
\end{tabular}

Observations: 433,699

Denied: $\quad 66,011$

Approved: $\quad 367,688$

Model Fitting Information and Testing Global Null Hypothesis BETA=0

$\begin{array}{ll}\text { Concordant Pairs } & =63.7 \% \\ \text { Discordant Pairs } & =35.4 \% \\ \text { Tied Pairs } & =0.9 \%\end{array}$

LR Test for Regressors: $\quad 13392.76(\mathrm{p}=0.0001)$

Notes: Table 2 presents binary logit estimates for the probability of being turned down on a mortgage application. The data are taken from the Home Mortgage Discrimination Act database for 1990-1995. Exemption quartiles are dummy variables which represent the size of the homestead exemption available in the relevant state. A pair of observations is defined as concordant (discordant) if the observation with the larger (smaller) response has a larger predicted probability. LR test indicates the chi-square statistic for joint significance of all regressors. Standardized estimates are normalized by the sample standard deviation of the associated regressor. 
Table 3. The Probability of Being Denied Credit and the Homestead Exemption

\begin{tabular}{|c|c|c|c|c|c|}
\hline Variable & $\begin{array}{l}\text { Parameter } \\
\text { Estimate }\end{array}$ & $\begin{array}{l}\text { Standard } \\
\text { Error }\end{array}$ & $\begin{array}{c}\text { Wald } \\
\text { Chi-Square }\end{array}$ & P-Value & $\begin{array}{l}\text { Standardized } \\
\text { Estimate }\end{array}$ \\
\hline Constant & -1.4643 & 0.1902 & 59.242 & 0.0001 & \\
\hline $2^{\text {nd }}$ quartile exemption & -0.1039 & 0.0283 & 13.513 & 0.0002 & -0.0247 \\
\hline $3^{\text {rd }}$ quartile exemption & -0.2053 & 0.0481 & 18.208 & 0.0001 & -0.0529 \\
\hline $4^{\text {th }}$ quartile exemption & -0.1658 & 0.0716 & 5.3588 & 0.0206 & -0.0323 \\
\hline Loan-to-Income ratio & 0.0020 & 0.0008 & 6.5348 & 0.0106 & 0.0135 \\
\hline Year91 & 0.1200 & 0.0196 & 37.601 & 0.0001 & 0.0205 \\
\hline Year92 & -0.0734 & 0.0179 & 16.733 & 0.0001 & -0.0161 \\
\hline Year93 & -0.2100 & 0.0178 & 139.65 & 0.0001 & -0.0512 \\
\hline Year94 & 0.0227 & 0.0185 & 1.5028 & 0.2202 & 0.0048 \\
\hline Year95 & 0.2864 & 0.0180 & 254.19 & 0.0001 & 0.0582 \\
\hline Income & -0.3331 & 0.0001 & 1282.0 & 0.0001 & -0.2659 \\
\hline Income squared & $3.6 \mathrm{e}-05$ & 0.0001 & 1079.8 & 0.0001 & 0.1868 \\
\hline Dummy for African-American & 0.7126 & 0.0176 & 1645.4 & 0.0001 & 0.0792 \\
\hline Dummy for female & -0.0287 & 0.0122 & 5.5750 & 0.0182 & -0.0059 \\
\hline Dummy for single & 0.2828 & 0.0105 & 731.77 & 0.0001 & 0.0688 \\
\hline Unemployment & 0.5638 & 0.3337 & 2.8548 & 0.0911 & 0.0049 \\
\hline
\end{tabular}

Model Fitting Information and Testing Global Null Hypothesis BETA=0

Concordant Pairs $=63.7 \%$
Discordant Pairs $=35.4 \%$
Tied Pairs $\quad=0.9 \%$

LR Test of Regressors: $\quad 13121.96(\mathrm{p}=0.0001)$

Notes: Table 3 presents binary logit estimates for the probability of being turned down on a mortgage application. Exemption refers to the homestead exemption available in bankruptcy in the relevant state. A pair of observations is defined as concordant (discordant) if the observation with the larger (smaller) response has a larger predicted probability. LR test indicates the chi-square statistic for joint significance of all regressors. 
Table 4. The Probability of Being Denied Credit

Homestead and Property Exemptions

\begin{tabular}{|c|c|c|c|c|c|}
\hline Variable & $\begin{array}{l}\text { Parameter } \\
\text { Estimate }\end{array}$ & $\begin{array}{l}\text { Standard } \\
\text { Error }\end{array}$ & $\begin{array}{c}\text { Wald } \\
\text { Chi-Square }\end{array}$ & P-Value & $\begin{array}{l}\text { Standardized } \\
\text { Estimate }\end{array}$ \\
\hline Constant & -1.5803 & 0.1878 & 70.771 & 0.0001 & \\
\hline Homestead exemption & -0.0321 & 0.0001 & 13.271 & 0.0003 & -0.05966 \\
\hline Property exemption & 0.1102 & 0.0010 & 1.3025 & 0.2538 & 0.05957 \\
\hline Loan-Income ratio & 0.0020 & 0.0008 & 6.5435 & 0.0105 & 0.01357 \\
\hline Year91 & 0.1180 & 0.0196 & 36.391 & 0.0001 & 0.02021 \\
\hline Year92 & -0.0730 & 0.0179 & 16.569 & 0.0001 & -0.01611 \\
\hline Year93 & -0.2092 & 0.0178 & 138.69 & 0.0001 & -0.05106 \\
\hline Year94 & 0.0219 & 0.0185 & 1.4112 & 0.2349 & 0.00465 \\
\hline Year95 & 0.2835 & 0.0180 & 247.28 & 0.0001 & 0.05768 \\
\hline Income & -0.3332 & 0.0001 & 1282.4 & 0.0001 & -0.26602 \\
\hline Income squared & $3.6 \mathrm{e}-05$ & 0.0001 & 1079.9 & 0.0001 & 0.18689 \\
\hline Dummy for African-American & 0.7131 & 0.0176 & 1647.4 & 0.0001 & 0.07935 \\
\hline Dummy for female & -0.0290 & 0.0122 & 5.6848 & 0.0171 & -0.00603 \\
\hline Dummy for single & 0.2817 & 0.0109 & 665.08 & 0.0001 & 0.06857 \\
\hline Unemployment & 0.8414 & 0.3322 & 0.0860 & 0.0113 & 0.07388 \\
\hline
\end{tabular}

Model Fitting Information and Testing Global Null Hypothesis BETA=0

Concordant Pairs $=63.7 \%$

Discordant Pairs $=35.4 \%$

Tied Pairs $\quad=0.9 \%$

LR Test of Regressors: $13111.9(\mathrm{p}=0.0001)$

Notes: Table 4 presents binary logit estimates for the probability of being turned down on a mortgage application. Exemption refers to the homestead exemption available in bankruptcy in the relevant state. A pair of observations is defined as concordant (discordant) if the observation with the larger (smaller) response has a larger predicted probability. LR test indicates the chi-square statistic for joint significance of all regressors. 
Table 5. State-level Fixed Effects Regression Estimates Homestead Exemptions

\begin{tabular}{lccr}
\hline \hline Variable & $\begin{array}{c}\text { Estimated } \\
\text { Coefficient }\end{array}$ & $\begin{array}{c}\text { Standard } \\
\text { Error }\end{array}$ & t-stati \\
\hline Mortgage Rates & & & \\
& & & \\
Homestead exemption & -0.036 & 0.023 & -1.542 \\
Property exemption & -0.182 & 0.486 & -0.374 \\
Unemployment rate & -0.628 & 0.908 & -0.692 \\
Wage rate & -0.076 & 0.059 & -1.301 \\
Percent African-American & 1.714 & 5.923 & 0.289 \\
Percent senior & 17.03 & 8.933 & 1.906 \\
Year91 & -0.641 & 0.047 & -13.68 \\
Year92 & -1.896 & 0.056 & -33.73 \\
Year93 & -2.769 & 0.069 & -40.05 \\
Year94 & -2.353 & 0.081 & -28.94 \\
Year95 & -1.991 & 0.094 & -21.11
\end{tabular}

Std. error of regression $=0.217$

R-squared $=0.964$

Adjusted R-squared $=0.956$

$\mathrm{F}$ test of $\mathrm{A}, \mathrm{B}=\mathrm{Ai}, \mathrm{B}: \mathrm{F}(50,244)=6.259, \mathrm{P}$-value $=[.000]$

Hausman test: $\chi^{2}(6)=5.170$, P-value $=[.522]$

Loan-to-Value Ratio

$\begin{array}{lrrr}\text { Homestead exemption } & -0.079 & 0.267 & -0.296 \\ \text { Property exemption } & -0.636 & 0.554 & -1.147 \\ \text { Unemployment rate } & -12.14 & 10.36 & -1.172 \\ \text { Wage rate } & 2.332 & 0.669 & 3.487 \\ \text { Percent African-American } & 11.41 & 67.57 & 0.169 \\ \text { Percent senior } & 325.6 & 101.9 & 3.195 \\ \text { Year91 } & -0.744 & 0.534 & -1.393 \\ \text { Year92 } & -0.631 & 0.641 & -0.984 \\ \text { Year93 } & -1.394 & 0.789 & -1.767 \\ \text { Year94 } & 0.362 & 0.927 & 0.391 \\ \text { Year95 } & 0.112 & 1.076 & 0.104\end{array}$

Std. error of regression $=2.480$

R-squared $=0.659$

Adjusted R-squared $=0.334$

F test of $\mathrm{A}, \mathrm{B}=\mathrm{Ai}, \mathrm{B}: \mathrm{F}(50,244)=4.340, \mathrm{P}$-value $=[.000]$

Hausman test: $\chi^{2}(6)=32.27$, P-value $=[.000]$

Notes: Linear regression model estimates of state-level mortgage rates and average mortgage loan to value ratios. Hausman (1978) test indicates specification test of random effects model against the alternative of the fixed effects model. 
Table 6

Probabilities of Denial of a Mortgage Application

for Typical Consumers

\begin{tabular}{|c|c|c|c|c|c|}
\hline & & $\begin{array}{l}\text { South } \\
\text { Carolina }\end{array}$ & Delaware & $\begin{array}{l}\text { West } \\
\text { Virginia }\end{array}$ & Mississippi \\
\hline $\begin{array}{l}\text { Homestead } \\
\text { Exemption }\end{array}$ & & 5,000 & 10,000 & 15,000 & 150,000 \\
\hline $\begin{array}{l}\text { Personal } \\
\text { Property } \\
\text { Exemption }\end{array}$ & & 5,400 & 10,000 & 19,200 & 20,000 \\
\hline \multicolumn{6}{|c|}{ Estimated Probabilities } \\
\hline & Low Income & .224 & .208 & .222 & .199 \\
\hline & $\begin{array}{l}\text { Middle } \\
\text { Income }\end{array}$ & .211 & .195 & .209 & .187 \\
\hline & High Income & .146 & .134 & .144 & .128 \\
\hline
\end{tabular}

Estimated Percentage Changes in Probabilities

\begin{tabular}{llllll}
\hline Quadruple & Low Income & -0.37 & -0.76 & -1.12 & -11.1 \\
$\begin{array}{l}\text { Homestead } \\
\text { Exemption }\end{array}$ & Middle & -0.38 & -0.77 & -1.34 & -11.2 \\
& Income & & & & \\
& High Income & -0.41 & -0.83 & -1.23 & -11.9 \\
& & & & & \\
Quadruple & Low & 1.39 & 2.54 & 5.02 & 5.40 \\
$\begin{array}{l}\text { Property } \\
\text { Exemption }\end{array}$ & Income & & & & \\
& Middle & 1.42 & 2.69 & 5.11 & 5.49 \\
& $\begin{array}{l}\text { Income } \\
\text { High Income }\end{array}$ & 1.54 & 2.90 & 5.56 & 5.91 \\
\hline \hline
\end{tabular}

Notes: Probabilities are fitted values from logit regression results shown in Table 4. Income levels are defined as less than $\$ 24,999$, between $\$ 25,000$ and $\$ 49,999$ and more than $\$ 50,000$. Each income category contains roughly one third of U.S. families (see Kennickel, StarrMcCluer and Sunden (1997). Loan-to-income ratios are set equal to the median values taken from the 1995 HMDA data for each income level. 
Table 7

Rates and Terms of a Mortgage Application for Typical Consumers

\begin{tabular}{|c|c|c|c|c|c|}
\hline & & $\begin{array}{l}\text { South } \\
\text { Carolina }\end{array}$ & Delaware & $\begin{array}{l}\text { West } \\
\text { Virginia }\end{array}$ & Mississippi \\
\hline $\begin{array}{l}\text { Homestead } \\
\text { Exemption }\end{array}$ & & 5,000 & 10,000 & 15,000 & 150,000 \\
\hline $\begin{array}{l}\text { Personal } \\
\text { Property } \\
\text { Exemption }\end{array}$ & & 5,400 & 10,000 & 19,200 & 20,000 \\
\hline \multicolumn{6}{|c|}{ Estimated Rates and Terms } \\
\hline & Rates & 7.79 & 7.54 & 7.91 & 8.23 \\
\hline & LTV Ratios & 84.3 & 8.30 & 79.5 & 81.0 \\
\hline \multicolumn{6}{|c|}{ Estimated Percentage Changes in Rates and Terms } \\
\hline $\begin{array}{l}\text { Quadruple } \\
\text { Homestead }\end{array}$ & Rates & -.070 & -.144 & -.206 & -1.97 \\
\hline Exemption & LTV Ratios & -.014 & -.029 & -.045 & -.440 \\
\hline $\begin{array}{l}\text { Quadruple } \\
\text { Property }\end{array}$ & Rates & .377 & .722 & 1.32 & 1.32 \\
\hline Exemption & LTV Ratios & -1.24 & 2.30 & -4.61 & -4.70 \\
\hline
\end{tabular}

Notes: Mortgage Rates and Loan-to-Value ratios are fitted values from logit regression results shown in Table 4. Income levels are defined as less than $\$ 24,999$, between $\$ 25,000$ and $\$ 49,999$ and more than $\$ 50,000$. Each income category contains roughly one third of U.S. families (see Kennickel, Starr-McCluer and Sunden (1997). Loan-to-income ratios are assumed equal to the median calculated from the 1995 HMDA data. 


\section{Appendix 1 \\ The Effect of Changes in the Property Exemption}

\section{Proof of Lemma 1}

By straightforward application of Leibniz's rule, the derivative of the lender's expected return, $\mathrm{E}(\mathrm{R})$ with respect to $\mathrm{X}_{\mathrm{h}}$ can be written as

$$
\left.\int_{h=M+X_{h}}^{H}\left[\int_{k=0}^{h-X_{h}-X_{p}} b_{X_{h}}\left(F_{7}-F_{n}+C_{n f}-C_{7 f}\right) j(k) d k+\int_{k=h-X_{h}-X_{p}}^{K_{d}} b_{X_{h}}\left(M-F_{n}+C_{n f}-C_{13}\right)+b\left(d C_{13} / d X_{h}\right) j(k)\right) f(h) d k\right] d h+
$$

$$
\int_{h=M+X_{h}}^{H}\left[j\left(R_{13}+h-X_{h}-X_{p}\right) b\left(M-F_{7}+C_{7 f}-C_{13}\right)+j\left(K_{d}\right)\left(d K_{d} / d X_{h}\right)\left((1-b)\left(M-F_{n}\right)+C_{r}-b C_{13}-(1-b) C_{n f}\right)\right] f(h) d h+
$$

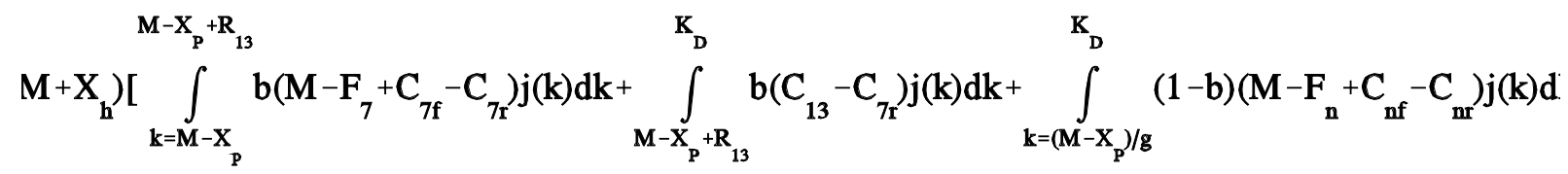

It remains now to sign the terms of the derivative. We maintain throughout that of $b_{E p}>0$, the probability of filing is increasing in the exemption. Assumptions one through three imply that every term from above is positive save one, $(1-b)\left(F_{N}-M\right)+C_{r}-b C_{13}-(1-b) C_{n f}$. The positivity of this term arises from assumption four. To see this, note that if $\mathrm{F}_{\mathrm{N}}<\mathrm{M}$, $\left(\mathrm{dK}_{\mathrm{D}} / \mathrm{d} \mathrm{X}_{\mathrm{h}}\right)=0$ as the debtor will only consider the homestead exemption if the mortgage creditor is repaid in full and he will receive some distribution after foreclosure. Therefore, the sign of this term depends again on the relative transactions costs. Becasue $C_{13}<C_{r}$, this is positive as long as $\mathrm{b}$ is sufficiently close to one. This will hold when $\mathrm{v}$ is large relative to $\mathrm{R}_{13}$ and $\mathrm{T}_{13}$ is small relative to $\mathrm{T}_{\mathrm{N}}$. QED. 


\section{Proof of Lemma 2}

The derivative of the home mortgage lender's expected return, $E(R)$, with respect to $X_{p}$ gives:

$$
\int_{h=0}^{M-v}\left(M-b F_{7}-(1-b) F_{n}+C_{r}-b C_{7 f}-(1-b) C_{n f}\right) j\left(K_{d}\right)\left(d K_{d} / d X_{p}\right) f(h) d h+
$$

$$
\int_{h=M-v}^{M+X_{h}}\left(C_{r}-b C_{7 r}-(1-b) C_{n r}\right) j\left(K_{d}\right)\left(d K_{d} / d X_{p}\right) f(h) d h+
$$

$$
\left.\int_{h=M+X_{h}}^{H}\left((1-b)\left(M-F_{n}\right)+C_{r}-b C_{13}-(1-b) C_{n f}\right)\right)\left(d K_{d} / d X_{p}\right) j\left(K_{d}\right) f(h) d h+
$$

$$
\int_{\mathrm{h}=0}^{\mathrm{M}-\mathrm{v}}\left(\int_{\mathrm{k}=0}^{\mathrm{K}_{\mathrm{d}}}\left(\mathrm{b}_{\mathrm{X}_{\mathrm{p}}}\left(\mathrm{F}_{7}-\mathrm{F}_{\mathrm{n}}+\mathrm{C}_{\mathrm{nf}}-\mathrm{C}_{7 \mathrm{f}}\right)+\mathrm{b}\left(\mathrm{dF}_{7} / \mathrm{dX} \mathrm{p}_{\mathrm{p}}\right)+(1-\mathrm{b})\left(\mathrm{dF}_{\mathrm{n}} / \mathrm{dX} \mathrm{P}_{\mathrm{p}}\right)\right) \mathrm{j}(\mathrm{k})\right) \mathrm{f}(\mathrm{h})+
$$

$$
\int_{h=M-v}^{M+X_{h}}\left(\int_{k=0}^{M-X}\left(b_{X_{p}}\left(F_{7}-F_{n}+C_{n f}-C_{7 f}\right)+b\left(d F_{7} / d X_{p}\right)+(1-b)\left(d_{n} / d X_{p}\right)\right) j(k) f(h)+\right.
$$

$$
\int_{h=M-v}^{M+X_{h}}\left(\int_{k=M-X_{p}}^{\left(M-X_{p}\right) / g}\left(b_{X_{p}}\left(M-F_{n}+C_{n f}-C_{7 r}\right)+(1-b)\left(d F_{n} / d X_{p}\right)+b\left(d_{7 r} / d X_{p}\right)\right) j(k) f(h)+\right.
$$




$$
\int_{h=M+X_{h}}^{H}\left[\int_{k=0}^{R_{13}+h-X_{h}-X_{p}} b_{X_{h}}\left(F_{7}-F_{n}+C_{n f}-C_{7 f}\right) j(k) d k+\int_{k=h-X_{h}-X_{p}}^{K_{d}}\left(b_{p}\left(M-F_{n}+C_{n f}-C_{13}\right)+b\left(d C_{13} / d X_{p}\right)\right) j(k) d k\right] f(h) d h+
$$

$$
\int_{h=M+X_{h}}^{H} j\left(R_{13}+h-X_{p}-X_{h}\right) b\left(M-F_{7}+C_{7 f}-C_{13}\right) f(h) d h+
$$

$$
\int_{h=M-v}^{M+X_{h}}\left[j\left(M-X_{p}\right)\left(b\left(M-F_{7}+C_{7 f}-C_{7 r}\right)\right)+(1 / g)\left(j\left(M-X_{p}\right) / g\right)\left((1-b)\left(M-F_{n}+C_{n f}-C_{n r}\right)\right] f(h) d h .\right.
$$

This unwieldy expression confirms that a change in $\mathrm{X}_{\mathrm{p}}$ has a much more ambiguous effect. Personal property exemptions enhance the debtor's wealth but also endanger deficiency judgments. Specifically, lines 14-16 indicate that larger personal property exemptions increase the chance that the debtor will default on his unsecured loans. In addition, a change in $\mathrm{X}_{\mathrm{p}}$ may now affect the debtor's willingness to repay his loans when the mortgagor is undersecured. If the debtor chooses to default on the mortgage creditor as well, the mortgagor will not be repaid in full. In addition, a rise in $X_{p}$ will weaken the power of the mortgagor to seek a deficiency judgment which is reflected by the fall in D as $X_{p}$ rises.

Lines 17-19 represent the effect of a rise in $X_{p}$ to cause more bankruptcies. As stated when discussing a change in the homestead exemption, an increase in bankruptcy filings may be good for the secured component of the loan through superior foreclosure procedures $\left(\mathrm{F}_{7}>\mathrm{F}_{\mathrm{n}}\right)$ and $\left(\mathrm{C}_{7 \mathrm{f}}<\mathrm{C}_{\mathrm{nf}}\right)$ and a greater ability of the debtor to reaffirm the mortgage. However, bankruptcy is bad for the unsecured portion of the loan, if it exists. That is, $\mathrm{D}_{\mathrm{n}}>\mathrm{D}$ ${ }_{7}$ due to a lack of garnishment and an increase in $X_{p}$ directly weakens the return to a deficiency judgment. Again, this was not an issue with the homestead exemption as a change in $\mathrm{X}_{\mathrm{h}}$ only has an effect on the debtor's decision when the mortgage creditor is fully secured.

Turning to lines 20-22, the personal property exemption increases the total wealth that the debtor has available to repay his mortgage or repay his unsecured creditors in return for 
retaining possession of the home. As $X_{p}$ rises, foreclosure becomes less likely. This may be especially important when the mortgage is undersecured but the debtor's private valuation exceeds the mortgage, $\mathrm{M}-\mathrm{v}<\mathrm{h}<\mathrm{M}+\mathrm{Q}$. In this case, a debtor able to repay results in full repayment while foreclosure may result in a substantial loss. 